\title{
COSSACKS' FARMS \\ IN THE CONDITIONS OF THE NEW ECONOMIC POLICY OF THE 1920s: CONTRADICTIONS OF DEVELOPMENT (ON THE MATERIALS OF THE DON AND KUBAN REGIONS)
}

\author{
Yuri A. Yakhutl \\ Kuban State University, Krasnodar, Russian Federation
}

\begin{abstract}
Introduction. The new economic policy is controversial, which manifested itself with a particular force in relation to the grain-producing regions - the Don and the Kuban, the most prosperous groups of farmers the Cossacks. The degree of recovery of Cossack farms and the level of their differentiation remains controversial. The purpose of the article is to determine the state and contradictions of the development of Don and Kuban Cossack farms in the conditions of the new economic policy of the 1920s. Methods and materials. The work is based on the method of synchronous binary comparative analysis. The source basis is data of economic and demographic statistics of the 1920s, reporting documents of the party and Soviet authorities. Analysis and Results. The article reveals the status and contradictory development trends of Cossack farms in the Don and Kuban in the 1920s. The paper proves that the economic and demographic potential of the Cossack farms in the Don and Kuban regions did not fully recover in the conditions of the NEP. As a result, the NEP measures reduced the number of seedless farms, while the reduction of large kulak farms was due to the expansion of medium-sized groups marginal and medium-sized ones. There was "equalizing" of the Cossacks, and to a greater extent than "nonresident" peasants. The high level of providing Cossack farms with land plots caused discontent among peasants, and property contradictions remained among Cossacks. The author proves the contradictions of the NEP in the agrarian sphere: between the needs of industrial modernization and the limits of tax possibilities of agriculture; between the authorities' intention to increase marketability of individual farms and the imperative to curb social inequality; between civil reconciliation and the equalizing land reform. The NEP period can be divided into four stages: between spring 1921 and summer 1924 - gradual revival of market relations stimulating restoration of individual Cossack farms; between autumn 1924 and spring 1926 - "facing the village" course resulting in tax cuts, resolving long-term leases, supporting cooperation and other forms of market self-organization of Cossack farms; summer 1926-1927 - gradual turn to the collapse of the NEP; the turn of 1927-1928 - systematic downturn of the NEP and transition to the full-scale application of administrative-command methods regulating the economy.
\end{abstract}

Key words: Cossack farms, new economic policy, development contradictions, Don, Kuban.

Citation. Yakhutl Yu.A. Cossacks' Farms in the Conditions of the New Economic Policy of the 1920s: Contradictions of Development (On the Materials of the Don and Kuban Regions). Vestnik Volgogradskogo gosudarstvennogo universiteta. Seriya 4. Istoriya. Regionovedenie. Mezhdunarodnye otnosheniya [Science Journal of Volgograd State University. History. Area Studies. International Relations], 2019, vol. 24, no. 4, pp. 124-134. (in Russian). DOI: https://doi.org/10.15688/jvolsu4.2019.4.11

\section{КАЗАЧЬИ ХОЗЯЙСТВА \\ В УСЛОВИЯХ НОВОЙ ЭКОНОМИЧЕСКОЙ ПОЛИТИКИ 1920-Х ГГ.: ПРОТИВОРЕЧИЯ РАЗВИТИЯ (ПО МАТЕРИАЛАМ ДОНА И КУБАНИ)}

\author{
Юрий Асланбиевич Яхутль
}

Кубанский государственный университет, г. Краснодар, Российская Федерация 
Аннотация. В статье раскрыто состояние и противоречивые тенденции развития казачьих хозяйств Дона и Кубани 1920-х гг. Доказано, что экономический и демографический потенциал казачьих хозяйств Дона и Кубани восстановился неполно в условиях новой экономической политики. В итоге мер НЭПа сократилось количество беспосевных хозяйств при сокращении крупных кулацких хозяйств за счет расширения средних групп - малопосевных и среднепосевных. Произошло «осереднячивание» казачества, причем в большей мере, чем «иногородних» крестьян. Более высокий уровень обеспеченности казачьих хозяйств земельными наделами вызывал недовольство крестьян, а внутри казачества сохранялись имущественные противоречия. Аргументированы противоречия НЭПа в аграрной сфере: между потребностями модернизации промышленности и пределами налоговых возможностей сельского хозяйства; между намерением властей повысить товарность индивидуальных хозяйств и императивом сдерживания социального неравенства; между гражданским примирением и уравнительной земельной реформой. Дана периодизация новой экономической политики на Дону и Кубани в аспекте ее влияния на развитие казачьих хозяйств. Период НЭПа можно разбить на четыре этапа: весна 1921-го - лето 1924 г. - постепенное возрождение рыночных отношений, стимулировавших восстановление индивидуальных казачьих хозяйств; осень 1924-го - весна 1926 г. - курс «лицом к деревне», что выразилось в снижении налогов, разрешении долгосрочной аренды, поддержке кооперации и иных форм рыночной самоорганизации казачьих хозяйств; лето 1926-го - 1927 г. постепенный поворот к свертыванию НЭПа; рубеж 1927-1928 гг. - системное свертывание НЭПа и переход к полномасштабному применению административно-командных способов регулирования экономики. Кубань.

Ключевые слова: казачьи хозяйства, новая экономическая политика, противоречия развития, Дон,

Цитирование. Яхутль Ю.А. Казачьи хозяйства в условиях новой экономической политики 1920-х гг.: противоречия развития (по материалам Дона и Кубани) // Вестник Волгоградского государственного университета. Серия 4, История. Регионоведение. Международные отношения. - 2019. - Т. 24, № 4. - С. 124-134. DOI: https://doi.org/10.15688/jvolsu4.2019.4.11

Введение. Новая экономическая политика 1920-х гг. остается одной из востребованных тем исследований. Вызывает особый интерес оценка развития индивидуальных земледельческих хозяйств, во многом обеспечившего быстрый восстановительный рост экономики. К началу 1928 г. уровень развития сельского хозяйства достиг уровня 1913 года. Период 19251926 гг. отмечен наивысшим расцветом индивидуального крестьянского хозяйства за весь советский период $[2 ; 5]$. Но новая экономическая политика противоречива, что с особой силой проявилось в отношении зернопроизводящих регионов - Дона и Кубани, более зажиточных групп земледельцев - казаков. Остается дискуссионной степень восстановления казачьих хозяйств и уровень их дифференциации. Цель статьи - определить состояние и противоречия развития казачьих хозяйств Дона и Кубани в условиях новой экономической политики 1920-х годов.

Методы и материалы. Работа основана на методе синхронного бинарного сравнительного анализа. Источниковой основой послужили данные экономической и демографической статистики 1920-х гг., отчетные документы партийных и советских органов вла- сти Дона и Кубани, информационные сводки и обзоры, делопроизводственная документация, размещенные в государственных архивах Ростовской области, Краснодарского края. В настоящее время открытость большей части архивных фондов 1920-х гг. позволяет использовать их для объективной оценки экономических процессов периода НЭПа, в том числе особенностей ее реализации в казачьих регионах Юга России. Следует обратить внимание на то, что при изучении архивных материалов были выявлены разночтения в оценке одних и тех же событий, что послужило основанием для проведения сравнительного анализа документов из различных фондов. Фонды Государственного архива Ростовской области содержат обобщающие отчеты и отличаются большей достоверностью и точным изложением событий 1920-х гг., что позволяет сравнить их с аналогичными материалами Государственного архива Краснодарского края. Качество информации, содержащейся в документах партийных, советских органов и партийных контрольных комиссий Дона и Кубани, использованных в статье, позволяет объективно оценить развитие казачьих хозяйств в годы НЭПа. 
В современной историографии активно исследуются такие аспекты НЭПа в казачьих регионах, как тенденции развития казачьих и крестьянских хозяйств Юга России (Т.В. Панкова-Козочкина и В.А. Бондарев, В.А. Савельев) [15; 22]; повседневная жизнь земледельцев (С.Д. Багдасарян, А.П. Скорик, И.М. Федина) $[1 ; 23]$; партийно-государственная аграрная политика (Р.Г. Тикиджьян, И.М. Федина) [27; 28]; общественное мнение казачества (А.В. Баранов, О.В. Рвачева) [3]. Но интерес к экономической динамике и социальной структуре казачества 1920 -х гг. снизился. Остаются невыясненными вопросы периодизации НЭПа.

Уникальность новой экономической политики 1920 -х гг. заключается в том, что она впервые сочетала государственное регулирование с частной инициативой. Отмена продразверстки, разрешение предпринимательской деятельности, развитие арендных отношений, стабилизация финансово-кредитной системы, развитие внутренней торговли способствовали достижению довоенного уровня сельского хозяйства России.

С другой стороны, НЭП характеризовался острыми противоречиями, поэтому можно говорить о закономерности его кризиса и замены на рубеже 1920-1930-х гг. моделью командно-мобилизационной экономики [11, с. 12].

Анализ. Российская империя, а затем РСФСР в 1914-1921 гг. переложила все тяготы военно-мобилизационных мероприятий на крестьянское хозяйство посредством мобилизации мужского трудоспособного населения, обеспечения армии продовольствием. События этого периода привели к невосполнимым экономическим потерям в сельскохозяйственном производстве Юга России и новым реформам в сельском хозяйстве. Аграрная политика большевиков в годы Гражданской войны, основанная на принципах «раскулачивания», уничтожила предпринимательские крестьянские и казачьи хозяйства, ориентированные на товарное производство и способные применять новые агротехнические приемы.

Обращаясь к состоянию экономики в начале 1920-х гг., мы понимаем, с какими трудностями столкнулась власть. В начале 1921 г. объем индустриального производства - $12 \%$ довоенного уровня, а производство железа и чугуна - 2,5\%. В сопоставлении с 1913 г. объем продукции на продажу снизился на $92 \%$. В стране к концу Гражданской войны объем выращенного зерна составлял $64 \%$ от довоенного уровня $[4$, с. 96$]$.

Целостную картину развития НЭПа нельзя воссоздать без изучения региональной специфики состава населения и рода его занятий. В РСФСР (по переписи 1926 г.) проживало 147 млн чел., из них в сельской местности - 121 млн чел. (82\%), в городах 26 млн чел. (18 \%) [10, с. 78]. В Кубано-Черноморской области проживало 1300 тыс. чел., из них в сельской местности $-84,6 \%$. Преобладающая часть населения (85 \%) занята в сельскохозяйственном производстве [24, л. 8]. В 1920 г. на Дону проживало 1495 тыс. казаков, а на Кубани - 1367 тыс. (по 43-44 \% всех жителей). Казачество использовало свыше 80 \% вовлеченных в сельскохозяйственный оборот земель Донской и Кубано-Черноморской областей, что на порядок превосходило землеобеспеченность «иногородних» и коренных крестьян [6, с. 14]. В этом - стержень противоречий аграрной сферы Южнороссийского региона.

Кубанская область отличалась высоким уровнем развития товарности крестьянского хозяйства. Первая четверть XX столетия характеризуется активным развитием арендных отношений в сельском хозяйстве при том, что $60 \%$ хозяйств использовали труд членов своих семей, 1,5 \% нанимали рабочую силу, а $10,5 \%$ - были батрацкими.

В первой половине 1920-х гг. вне сельского хозяйства - в строительной индустрии было занято $6,07 \%$. В сельском хозяйстве использовался труд 120 тыс. батраков и полубатраков, способствовавших формированию рынка сельскохозяйственных рабочих [21, л. 29, 14].

Экономика Дона и Кубани после Гражданской войны находилась в тяжелом положении. По мнению руководства РСФСР, зерновые регионы в этих условиях должны поставлять хлеб в ущерб своей продовольственной безопасности [29, л. 15].

В резолюции Х съезда РКП(б) (март 1921 г.) «О кооперации» отмечено, что новая продовольственная налоговая система придерживается классовых принципов, но поддер- 
живает хозяйства крестьян, ориентированные на «увеличение площади засева в своих хозяйствах» [12, с. 371]. Инициируя выполнение хлебозаготовок, органы власти брали на себя обязательства по поставкам сельхозорудий, мануфактуры, что подталкивало большинство казаков и крестьян сдавать зерно в ущерб своим хозяйствам.

Начало реформ ознаменовалось нарастанием повстанческого движения казаков и, в меньшей мере, крестьян. Местное население находилось под двойным давлением: советская власть военно-административными методами реквизировала продовольствие, а повстанцы тоже требовали от хлеборобов политической и экономической поддержки $[19$, л. 8].

Переход к НЭПу вызвал восстановление основных отраслей сельского хозяйства в казачьих регионах Юга России, но спровоцировал рост сословных и классовых противоречий в станицах. Окончание войны, кардинальное изменение политики правительства способствовали возрождению старых конфликтов внутри станицы: земельных споров из-за миграционного прироста сельскохозяйственного населения и дробления крестьянских хозяйств. Доверие казаков Дона к продовольственному налогу стало падать, так как методы его проведения, как и в Кубано-Черноморской области, были схожи с методами «военного коммунизма» [20, л. 11].

Налицо сложные конфликты на Дону и Кубани 1920-х гг., сторонами которых были и казаки, и «иногородние», и коренные крестьяне. Высокий уровень обеспеченности казачьих хозяйств земельными наделами вызывал недовольство у крестьян, а внутри казачества сохранялись имущественные противоречия. Желание власти уравнять в землепользовании крестьянство и казачество провоцировало нарастание социального противостояния в станицах Юга России, ставило под угрозу рыночные начала в аграрном секторе экономики. Средний казак, который составлял большинство казачьего населения, по сути своей был крепким хозяином и для него естественна личная свобода. Поэтому большинство казаков стремилось сохранить свои земельные привилегии, общинную форму землепользования, формы казачьего самоуправления. Произошло значительное обострение социально-клас- совых противоречий между казачьим и крестьянским населением.

Формирование аграрной политики в первые годы НЭПа на Дону и Кубани имело ряд особенностей. Они определялись полиэтничным составом населения, особым менталитетом казачества, отсутствием подготовленных кадров управления, полувоенными методами руководства большевиков.

После голода 1921 г., относительно высокого урожая 1922 г., способствовавшего незначительному расширению местного рынка, снижению налогообложения, в 1924 г. сельское хозяйство стремилось выйти из состояния стагнации и нарастить темпы восстановления.

Рыночный оборот продукции сельского хозяйства в значительной мере рос вследствие снижения потребления самих земледельцев и расходования основного капитала. Возможность капитализации при таких условиях чрезвычайно затруднительна, что могли себе позволить только самые крепкие хозяйства. Благоприятные перспективы относительно развития площадей посевов, рост урожайности трех лет (19221924 гг.) осложнились серьезным снижением площади посева озимых в 1925 г., уменьшением поголовья рабочего скота, что было связано с последствиями неблагоприятных рыночных конъюнктур 1923 г., высоким уровнем налогообложения и легло основной тяжестью на середняцкие хозяйства Кубани и Дона.

С 1920 по 1924 г. произошли серьезные изменения в социальном расслоении кубанского казачества. В 1920 г. беспосевных хозяйств было 29,7 \%, с посевом меньше 4 дес. 24,1\%, от 4 до 10 дес. - 30,5 \%, более 10 дес. $15,7 \%$. В 1924 г. беспосевных хозяйств стало $15,1 \%$, с посевом меньше 4 дес. $-32,6 \%$, от 4 до 10 дес. $-38,8 \%$ и больше 10 дес. $-13,5 \%$ [25, л. 34]. Дробление хозяйств за 1923 г. замедлились, что позитивно сказалось на состоянии сельского хозяйства. В 1924 г. в итоге проведенного землеустройства и гибкой налоговой политики сократилось количество беспосевных хозяйств, а также зажиточных хозяйств, расширились малопосевная и среднепосевная группы хозяйств.

Эволюция сельского хозяйства Юга России в 1922-1924 гг. характеризуется интенсивным развитием посевных площадей, что объяснялось, с одной стороны, сокращением 
числа беспосевных в итоге землеустроительных работ, а с другой - значительным оживлением зажиточной части казачества ввиду расширения рыночных отношений.

Проведенные органами власти мероприятия в сфере землепользования не могли гарантировать возможности избежать конфликтов между беднотой и средними слоями, с одной стороны, и зажиточными слоями станицы - с другой. Классовые принципы большевиков не всегда могли оказать существенную поддержку и помощь беднейшей части казачества. Полностью уравнять земельные наделы казаков и крестьян оказалось чрезвычайно трудно. В этих условиях заметно стремление бедняков уйти на хутора, подальше от зажиточных соседей. Большевики, опасаясь настроить против себя среднее и беднейшее казачество, не покушались на его трудовые наделы. Поэтому на Дону и Кубани в 1920-х гг. размеры землепользования казачьих хозяйств оставались выше по сравнению с крестьянскими.

Вопрос о хлебозаготовках был главным в годы НЭПа и определяющим в формировании взаимоотношений сельского населения и государства. Возобновление экспорта зерна в 1923 г. обострило указанные взаимоотношения, так как эти средства использовались на нужды индустриализации.

Для сельского хозяйства региона характерно, что 50 \% произведенной продукции хлеборобы оставляли для собственного потребления. В связи с изменением общего сбора размеры товарных излишков казачьих хозяйств Кубанского округа в 1926 г. снизились до 645772 т против 893399 т в 1925 г. (на $27,15 \%$ ). Это привело к снижению сырьевой базы основной отрасли промышленности округа - мукомольно-маслобойной [13, с. 7].

В 1925 г. мы наблюдаем значительное расслоение крестьянских хозяйств на юге страны, где сформировалась довольно большая группа беспосевных хозяйств $(11 \%)$ и посевной площадью ниже 1 дес. (6,8 \%). Если сравнивать группы крестьянских хозяйств со средними показателями по РСФСР, то помимо более крупных размеров посевной площади в хозяйствах казаков необходимо отметить и значительное их социальное расслоение. По данным выборочных обследований ЦСУ
РСФСР (265 тыс. хозяйств), оглашенных председателем Совнаркома СССР А.И. Рыковым на XIV Московской губернской партконференции, беспосевных хозяйств по всей РСФСР насчитывалось 1,8 \%, по Северо-Кавказскому краю $-6,9 \%$, а по Кубанскому округу 1,1\%; с посевом от 1 до 4 дес. по РСФСР 60,9 \%, по Северо-Кавказскому краю - 33,2 \%, а по Кубанскому округу - 27,3\%; от 4 до 10 дес. по РСФСР - 23,7 \%, по Северо-Кавказскому краю - 35,2 \%, а по Кубанскому округу $-39,2 \%[8$, с. 6$]$. Таким образом, зерновой Кубанский округ выделялся повышенным уровнем посевов, а бедняк на Кубани напоминал середняка средней полосы России по своим хозяйственным возможностям.

Донское сельское хозяйство, в отличие от кубанского, характеризовалось наличием повышенного процента малопосевных и крупнопосевных хозяйств. Посевные группы области были распределены краевым статистическим управлением в 1924/25 хозяйственном году по следующим группам: II группа - от 0,1 до 2 дес. земли; III группа - от 2 до 4 дес.; IV группа - от 4 дес. до 6 дес.; VI группа - от 10 до 16 дес.; VII группа - свыше 16 дес. [9, с. 21].

Наивысшего расцвета НЭП достиг в период 1925-1926 гг., когда российская деревня развивалась почти без административных мер воздействия, в рамках относительно рыночной хлебозаготовительной кампании. Деревня и государство находились в стадии равновесия сил и относительного взаимопонимания. Например, партийные организации планировали предоставление налоговых льгот для $25-30$ \% казачьих хозяйств [14, л. 24]. Льготное налогообложение получали и арендованные земли в случае официальной регистрации договора аренды, причем долгосрочной. Это был инструмент вывода «из тени» скрытой аренды земли, способствовавшей установлению экономической зависимости беднейшей части казачества от зажиточных казаков.

Понимая, что НЭП стал следствием социально-политического и экономического кризиса во взаимоотношениях государства и крестьянства, в первую очередь, большевики стремились получить положительный результат именно в сельском хозяйстве, избежав повторения голода, путем формирования государственных продовольственных резервов. 
Темпы модернизационных преобразований в сельском хозяйстве на начальном этапе НЭПа в малой степени зависели от финансово-материальных возможностей государства. Индивидуальное казачье-крестьянское хозяйство развивалось на основе собственных потенциальных возможностей. К 1925 г. посевные площади на Дону выросли на 17 \% относительно показателей 1917 года. Но оставались трудности в восстановлении поголовья тягловой живой силы: так, на одну лошадиную силу в 1917 г. приходилось 3,39 дес. земли, а в 1925 г., соответственно, $-5,98$ дес. В некоторых районах области эти показатели достигали и 11 дес. земли [16, л. 41].

Качество земли в округах Дона сильно различалось, что влияло на размеры казачьих хозяйств. Трудовые паи сокращались с севера на юго-запад, меньше всего они были в Черкасском и Ростовском округах. Напротив, в Сальском, Усть-Медведицком и Хоперском округах почвы малоплодородны. Поэтому в Хоперском округе казаки получали 4,55,5 дес., а в Ростовском - 3-3,5 дес. земли $[18$, л. 71$]$. В Хоперском округе во многих хуторах насчитывалось лишь 15 лошадей и $1-$ 2 пары волов. В Ростовском округе в 1921 г. зарегистрировано 74 тыс. лошадей, а в 1922 г. осталось 27 тыс., то есть произошло сокращение поголовья на $64 \%$; количество рабочих волов сократилось с 23 тыс. до 11 тыс. (на $50 \%$ ). Состояние дел в Морозовском округе было аналогичным: сокращение лошадей с 18 тыс. до 7 тыс. (61\%); количества рабочих волов с 43 тыс. до 24 тыс. (на 50 \%). В округе на 1 лошадь приходилось до 3 дес. земли [26, л. 15]. Задача увеличения посевных площадей с такими возможностями крестьянских хозяйств не могла быть выполнена. Поэтому аграрные реформы были в период НЭПа в основном сопряжены с реализацией Земельного кодекса РСФСР.

Развитие арендных отношений в середине 1920-х гг. на Дону свидетельствовало о нарастании социального противостояния и имущественной поляризации казачьей станицы. Расширение арендных отношений, рост найма рабочей силы способствовали расширению и росту товарности сельского хозяйства. Основными арендодателями земли выступали беднейшие хозяйства - до $75 \%$, а арендаторами выступали середняцкие хозяйства - до 70 \% [17, л. 73]. Развитие арендных отношений инициировало восстановительный процесс маломощных хозяйств и одновременно вело к росту материального благосостояния зажиточной части казачества. Пользуясь возможностью устанавливать и влиять на условия аренды, зажиточные казаки, как правило, арендовали земли по заниженным ставкам, без регистрации договора аренды, на условиях натуральной арендной платы.

Вопрос о найме рабочей силы был сложным и противоречивым, так как в нем смешались как рыночные принципы, так и патриархальные, традиционные для Юга России, определявшиеся особыми условиями казачьего землепользования. Размер применения наемного труда в казачьих хозяйствах Дона был значительным, но, в отличие от Кубани, предложения рынка труда превышали спрос. Рынок сельскохозяйственных батраков рос за счет неконтролируемого прибытия батраков из других регионов Советской России. Советские органы вынуждены были признавать, что вопросы аренды земли, арендной платы, процесс заключения договоров и деятельность батраков не контролировались и проходили в системе рыночных отношений, развивающихся в сельском хозяйстве Юга России.

Активное развитие арендных отношений на Дону связано с приоритетами в сельском хозяйстве - полеводством и животноводством. На Кубани, в отличие от Дона, широкое распространение получили индивидуальное огородничество и виноградарство, особенно на Черноморском побережье.

С 1924-го по осень 1926 г. мы наблюдаем сглаживание сословных различий между казачеством и крестьянством. Землеустроительные работы в этот период проводились в основном не по классовому принципу, а с целью сгладить межселенное неравенство, чересполосицу, дальноземелье в землепользовании. Община («земельные общества») впервые на Кубани и Дону приобрела межсословный характер. Тем самым, взаимоотношения казачества и крестьянства регулировались в данный период на основе рыночных принципов и мотиваций.

Однако рост организованности зажиточных и середняцких слоев казачества, проявив- 
шийся на местных выборах в Советы и в кооперации 1925-1926 гг., укрепление предпринимательской группы крестьянства в целом побудили партийные и государственные органы власти перейти летом 1926 г. к постепенному свертыванию НЭПа. Это проявилось в росте прогрессии налогообложения, вытеснении зажиточных хлеборобов из Советов и кооперативных органов, блокировании кредитования предпринимательских верхов станиц Дона и Кубани.

Хлебозаготовительная кампания 1927 1928 гг. положила начало новому периоду в развитии аграрной составляющей НЭПа, связанной с переходом к административно-командным методам регулирования экономики, с начальным этапом раскулачивания. Советское государство подошло к коллективизации сельского хозяйства подготовленным, способным подавить сопротивление. Немаловажным фактором мы считаем и психологическую подготовку земледельцев к проведению коллективизации, которая проявлялась в разьяснительной и политико-просветительной деятельности, распространении, а во многих случаях в насаждении коллективных форм хозяйства в станицах.

Январь 1928 г. ознаменовался введением в действие статей Уголовного Кодекса РСФСР, принятого в 1926 г., а именно - ст. 107 (спекуляции частных скупщиков), ст. 105 - против «пособников спекуляции из низового аппарата», ст. 60 - против недоимщиков при взимании налогов и других платежей, применительно к хлебозаготовкам. С началом 1928 г. ст. 107, действовавшая против спекулянтов и перекупщиков, стала применяться против крестьян, не желавших сдавать хлеб. Нежелание добровольно сдавать хлеб было вполне объяснимо низкими закупочными ценами. В свою очередь, это провоцировало массовый отказ ссыпать в пункты приема зерно либо другое продовольствие, а государство получало повод для активизации репрессий. Чрезвычайные меры хлебозаготовок обострили также сословные и классовые конфликты на Дону и Кубани.

Объединенный пленум ЦК и ЦКК ВКП(б) 11-16 апреля 1928 г. вынужден констатировать: «Несмотря на то, что кулак и частник в общем обладают куда меньшими силами, чем мы, надо отметить, что в общем процессе роста деревни кулак вырос еще больше. Он пользуется значительным хозяйственным авторитетом в деревне, будучи относительно слабым в политическом отношении» [7, с. 39]. В итоге возобладали административные методы коллективизации казачьих и крестьянских хозяйств.

Результаты. Доказано, что экономический и демографический потенциал казачьих хозяйств Дона и Кубани восстановился неполно в условиях новой экономической политики. Кубанские казачьи хозяйства являлись более зажиточными, чем донские. Аргументированы противоречия НЭПа в аграрной сфере: между потребностями модернизации промышленности и пределами налоговых возможностей сельского хозяйства; между намерением властей повысить товарность индивидуальных хозяйств и императивом сдерживания социального неравенства; между гражданским примирением и уравнительной земельной реформой.

Период НЭПа можно разбить на четыре этапа: весна 1921-го - лето 1924 г. - этап умеренного возрождения рыночных отношений, стимулировавших восстановление индивидуальных казачьих хозяйств; осень 1924-го весна 1926 г. - реализация курса «лицом к деревне», что выразилось в снижении налогов, разрешении долгосрочной аренды, поддержке кооперации и иных форм рыночной самоорганизации казачьих хозяйств; лето 1926-го 1927 г. - постепенный поворот аграрной политики к свертыванию НЭПа; рубеж 19271928 гг. - системное свертывание НЭПа и переход к полномасштабному применению административно-командных способов регулирования экономики.

\section{СПИСОК ЛИТЕРАТУРЫ}

1. Багдасарян, С. Д. Сельская повседневность на Юге России в эпоху НЭПа: устойчивость традиций и противоречия преобразований : дис. ... д-ра ист. наук / Багдасарян Сусанна Джамиловна. - Новочеркасск, 2017. - 869 с.

2. Баранов, А. В. Тенденции гражданского примирения в политических реформах «расширения» нэпа 1924-1926 гг. на Юге России / А. В. Баранов // Научная мысль Кавказа. - 2013. - № 3. - С. 55-62. 
3. Баранов, А. В. Протестные настроения донского казачества и репрессивная политика власти конца 1920-х - 1930-х годов / А. В. Баранов, О.В.Рвачева // Новейшая история России. 2018. - T. 8, № 3. - С. 613-624.

4. Верт, Н. История советского государства. 1900-1991 / Н. Верт. - М. : Прогресс : ПрогрессАкадемия, 1992. - 480 с.

5. Данилов, В. П. Советская деревня к началу реконструктивного периода / В. П. Данилов // Данилов, В. П. История крестьянства России в XX веке : Избранные труды : в 2 ч. / В. П. Данилов. - М. : Российская политическая энциклопедия (РОССПЭН), 2011. - Ч. 1. - С. 83-130.

6. Домбровский, В. В. Донское казачество в период нэпа / В. В. Домбровский // Государство, право, казачество: история и современность : материалы регион. науч.-практ. конф., Санкт-Петербург, 4 июля 2012 г. - СПб. : ГУАП, 2012. - С. 12-15.

7. Как ломали нэп : Стенограммы пленумов ЦК ВКП (б) 1928-1929 гг. : в 5 т. Т. 1. Объединенный пленум ЦК и ЦКК ВКП(б) 6-11 апреля 1928 г. / редкол. тома В. П. Данилов, О. В. Хлевнюк (отв. ред.). М. : МФД, 2000. - 495 с.

8. Конюков, И. А. Очерки производственных типов крестьянских хозяйств Кубани. Очерк 1-й / И. А. Конюков. - Краснодар : Кубан. окрисполком, 1927. $-44 \mathrm{c}$.

9. Крестьянские бюджеты Северо-Кавказского края за 1924-25 г. - Ростов н/Д : Северо-Кавказское статистическое управление, 1927. - 42 с.

10. Муравьева, Л. А. Новая экономическая политика: результаты, противоречия и тупики развития / Л. А. Муравьева // Финансы и кредит. 2002. - № 21 (111)- С. 78-87.

11. Надеждина, В. А. Модернизация и НЭП: к вопросу о причинах провала «нэповского пути к социализму / В. А. Надеждина // Вестник Оренбург. гос. университета. - 2005. - №9 (47). - С. 8-13.

12. О кооперации. Резолюция Десятого съезда РКП(б) // Коммунистическая партия Советского Союза в резолюциях и решениях съездов, конференций и пленумов ЦК (1898-1986). Изд. 9-е, доп. и испр. - М. : Политиздат, 1983. T. 2. - C. 371.

13. Обзор конъюнктуры народного хозяйства Кубанского округа в 1926-1927 году. - Краснодар : Кубанская окружная плановая комиссия при Кубокриспокома, 1928. - $48 \mathrm{c}$.

14. Отчеты и доклады ВКП(б) и материалы проверки предприятий и организаций за 1925 год и 1926 год // Центр документации новейшей истории Краснодарского края (ЦДНИ КК). - Ф. 10. - Оп. 1. Д. 55. -174 л.

15. Панкова-Козочкина, Т. В. Казачье-крестьянское хозяйство эпохи нэпа: проблемы модерни- зации аграрных отношений на Юге России / Т. В. Панкова-Козочкина, В. А. Бондарев. - Новочеркасск : Лик, 2012. - 266 с.

16. Протоколы № 13-27 заседания бюро Донкома ВКП(б) и материалы к ним // Центр документации новейшей истории Ростовской области (ЦДНИ РО). - Ф. 5. - Оп. 1. - Д. 52. - 190 л.

17. Протоколы № 55-58 заседания бюро Донкома ВКП(б) и материалы к ним // ЦДНИ РО. Ф. 5. - Оп. 1. - Д. 54. -153 л.

18. Протоколы заседаний пленумов и президиумов Северо-Кавказского крайисполкома за 1925 год и материалы к ним // Государственный архив Ростовской области (ГАРО). - Ф. Р 1485. Оп. 1. - Д. 169. - 420 л.

19. Протоколы заседания пленумов Донкома РКП(б) № 1-2 от 15 апреля. № 4 от 5, 7 июня, 8, 31 июля № 1, 2, 3, 4, 5, 1 // ЦДНИ РО. - Ф. 4. - Оп. 1. - Д. 73. -71 л.

20. Протоколы заседания пленумов Донкома РКП(б) от 15 апреля, 20 мая, 5 июня, 8, 3 июля № 13, 1 // ЦДНИ РО. - Ф. 4. - Оп. 1. - Д. 74. - 47 л.

21. Разная секретная переписка, циркуляры, ЦК РКП(б) и ЦКК // ЦДНИ КК. - Ф. 13. - Оп. 1. Д. 24. -144 л.

22. Савельев, В. А. Хозяйственные представления крестьянства и казачества в условиях новой экономической политики: особенности трансформации (на материалах Дона и Кубани) / В. А. Савельев. - Армавир : Армавир. гос. пед. академия, 2012. -159 c.

23. Скорик, А. П. Кубанский хутор: фазы и повседневность топохронной эволюции (конец XVIII первая треть XX вв.) / А. П. Скорик, И. М. Федина. Новочеркасск : Лик, 2016. - 420 с.

24. Стенограмма 1-го Областного съезда Сoвета рабочих, крестьянских и казачьих депутатов // Государственный архив Краснодарского края (ГАКК). - Ф. Р 102. - Оп. 1. - Д. 152. - 255 л.

25. Стенограмма 1-ой Кубанской окружной конференции РКП(б) // ЦДНИ КК. - Ф. 8. - ОП. 1. Д. 12. - 110 л.

26. Стенографический отчет VI областного съезда Советов Донской области. Речь Микояна // ЦДНИ РО. - Ф. 4. - Оп. 1. - Д. 23. - 546 л.

27. Тикиджьян, Р. Г. Политика советского государства «Лицом к деревне» и проблемы взаимоотношений казачества, крестьянского и иногороднего населения Дона в 1920-е годы / Р. Г. Тикиджьян // Известия высших учебных заведений. СевероКавказский регион. Общественные науки. - Ростов н/Д, 2011. - № 3 (163). - С. 46-50.

28. Федина, И. М. Регулирование земельных отношений на Кубани в 1920-е годы / И. М. Федина // Историческая и социально-образовательная мысль. -2016. - Т. 8, № 2-1. - С. 39-45. 
29. Циркуляры областного отдела управления о борьбе с бело-зелеными, чистке милиции, выполнении продразверстки и переписка с Кубано-Черноморским областным управлением милиции и отдельским отделом управления по этим вопросам // ГАКК. - Ф. Р 102. - ОП. 1. - Д. 9. - 40 л.

\section{REFERENCES}

1. Bagdasaryan S.D. Selskaya povsednevnost na Yuge Rossii v epokhu NEPa: ustoychivost traditsiy i protivorechiya preobrazovaniy. Dis. ... d-ra ist. nauk [Rural Everyday Life in the South of Russia in the Era of the NEP. Stability of Traditions and Contradictions of Transformations. Dr. hist. sci. diss.]. Novocherkassk, 2017.869 p.

2. Baranov A.V. Tendentsii grazhdanskogo primireniya v politicheskikh reformakh «rasshireniya» nepa 1924-1926 gg. na Yuge Rossii [Tendencies of Civil Reconciliation in the Political Reforms of the NEP "Expansion" of 1924-1926 in the South of Russia]. Nauchnaya mysl Kavkaza [Scientific Thought of Caucasus], 2013, no. 3, pp. 55-62.

3. Baranov A.V., Rvacheva O.V. Protestnye nastroeniya donskogo kazachestva i repressivnaya politika vlasti kontsa 1920-kh - 1930-kh godov [Protest Sentiments of the Don Cossacks and the Repressive Policy of the Authorities in the Late 1920s - 1930s]. Noveyshaya istoriya Rossii [Modern History of Russia], 2018, vol. 8, no. 3, pp. 613-624.

4. Vert N. Istoriya sovetskogo gosudarstva. 1900-1991 [History of the Soviet State. 1900-1991]. Moscow, Progress Publ., Progress-Akademiya Publ., 1992. $480 \mathrm{p}$.

5. Danilov V.P. Sovetskaya derevnya k nachalu rekonstruktivnogo perioda [The Soviet Village at the Beginning of the Reconstruction Period]. Istoriya krestyanstva Rossii v XX veke. Izbrannye trudy: v 2-h ch. [History of the Peasantry of Russia in the $20^{\text {th }}$ Century. Selected Works. In 2 Parts]. Moscow, Rossiyskaya politicheskaya entsiklopediya (ROSSPEN) Publ., 2011, part 1, pp. 83-130.

6. Dombrovskiy V.V. Donskoe kazachestvo v period nepa [The Don Cossacks in the Period of the New Economic Policy]. Gosudarstvo, pravo, kazachestvo: istoriya i sovremennost: materialy region. nauch.-prakt. konf. Sankt-Peterburg, 4 iyulya 2012 g. [State, Law, the Cossacks. History and Modernity. Materials of the Regional Scientific and Practical Conference]. Saint Petersburg, July 4, 2012]. Saint Peterburg, GUAP, 2012, pp. 12-15.

7. Danilov V.P., Khlevnyuk O.V., eds. Kak lomali nep. Stenogrammy plenumov TsK VKP (b) 1928-1929 gg. V 5-ti t. T. 1. Obyedinennyy plenum TsK $i$ TsKK VKP (b) 6-11 aprelya 1928 g. [How They
Broke the NEP. Shorthand Transcripts of Plenary Sessions of the Central Committee of the All-Union Communist Party (Bolsheviks) of 1928-1929. In 5 vols. Vol. 1. Joint Plenum of the Central Committee and the Central Control Commission of the All-Union Communist Party (Bolsheviks) of April 6-11, 1928]. Moscow, MFD Publ., 2000. 495 p.

8. Konyukov I.A. Ocherki proizvodstvennykh tipov krestyanskikh khozyaystv Kubani. Ocherk 1-y [Essays on the Production Types of Peasant Households of the Kuban Region. Essay 1]. Krasnodar, Kubanskiy Okrispolkom, 1927. 44 p.

9. Krestyanskie byudzhety SeveroKavkazskogo kraya za 1924-25 g. [Peasant Budgets of the North Caucasus Region for 1924-25]. Rostovon-Don, Severo-Kavkazskoe statisticheskoe upravlenie, $1927.42 \mathrm{p}$.

10. Muravyeva L.A. Novaya ekonomicheskaya politika: rezultaty, protivorechiya i tupiki razvitiya [New Economic Policy. Results, Contradictions and Development Dead Ends]. Finansy $i$ kredit [Finance and Credit], 2002, no. 21 (111), pp. 78-87.

11. Nadezhdina V.A. Modernizatsiya i NEP: $k$ voprosu o prichinakh provala «nepovskogo puti $\mathrm{k}$ sotsializmu» [Modernization and the NEP. To the Issue of Reasons for the Failure of the "NEP Road to Socialism"]. Vestnik Orenburg. gos. universiteta [Vestnik of the Orenburg State University], 2005, no. 9 (47), pp. 8-13.

12. O kooperatsii. Rezolyutsiya Desyatogo syezda RKP (b) [About Cooperation. Resolution of the Tenth Congress of the Russian Communist Party (Bolsheviks).]. Kommunisticheskaya partiya Sovetskogo Soyuza v rezolyutsiyakh $i$ resheniyakh syezdov, konferentsiy i plenumov TsK (1898-1986) [Communist Party of the Soviet Union in Resolutions and Decisions of Congresses, Conferences and Plenums of the Central Committee (1898-1986)]. Moscow, Politizdat, 1983, vol. 2, p. 371.

13. Obzor konyunktury narodnogo khozyaystva Kubanskogo okruga v 1926-1927 godu [Review of the State of the Kuban District Economy in 1926-1927]. Krasnodar, Kubanskaya okruzhnaya planovaya komissiya pri Kubokrispokome, 1928. 48 p.

14. Otchety i doklady VKP(b) i materialy proverki predpriyatiy i organizatsiy za $1925 \operatorname{god} \mathrm{i}$ 1926 god [Reports and Papers of the All-Union Communist Party (Bolsheviks) and Audit Materials of Enterprises and Organizations for 1925 and 1926]. Tsentr dokumentatsii noveyshey istorii Krasnodarskogo kraya (CDNI KK) [Documentation Centre of Modern History of Krasnodar Krai], F. 10, Op. 1, D. 55. 1741.

15. Pankova-Kozochkina T.V., Bondarev V.A. Kazachye-krestyanskoe khozyaystvo epokhi nepa: problemy modernizatsii agrarnykh otnosheniy na Yuge 
Rossii [Cossack-Peasant Economy of the NEP Era. Problems of Modernizing Agrarian Relations in the South of Russia]. Novocherkassk, Lik Publ., 2012. 266 p.

16. Protokoly № 13-27 zasedaniya byuro Donkoma VKP(b) i materialy k nim [Minutes no. 13-27 of Meetings of the All-Union Communist Party (Bolsheviks) Don Committee Bureau and Materials to Them]. Tsentr dokumentatsii noveyshey istorii Rostovskoy oblasti (TsDNIRO) [Documentation Centre of Modern History of Rostov Region], F. 5, Op. 1, D. 52. 1901.

17. Protokoly № 55-58 zasedaniya byuro Donkoma VKP(b) i materialy k nim [Minutes no. 55-58 of Meetings of the All-Union Communist Party (Bolsheviks) Don Committee Bureau and Materials to Them]. Tsentr dokumentatsii noveyshey istorii Rostovskoy oblasti (TsDNIRO) [Documentation Centre of Modern History of Rostov Region], F. 5, Op. 1, D. 54. 1531.

18. Protokoly zasedaniy plenumov i prezidiumov Severo-Kavkazskogo krayispolkoma za 1925 god i materialy k nim [Minutes of Meetings of the North Caucasus Regional Executive Committee Plenums and Presidiums for 1925 and Materials to Them]. Gosudarstvennyy arkhiv Rostovskoy oblasti (GARO) [State Archive of Rostov Region], F. R 1485, Op. 1, D. 169. 4201.

19. Protokoly zasedaniya plenumov Donkoma RKP(b) №1-2 ot 15 aprelya. № 4 ot 5, 7 iyunya, 8, 31 iyulya № 1, 2, 3, 4, 5, 1 [Minutes of the Meeting of the Russian Communist Party (Bolsheviks) Don Committee Plenums no. 1-2 of April 15, no. 4 of June 5, 7, July 8, 31, no. 1, 2, 3, 4, 5, 1]. Tsentr dokumentatsii noveyshey istorii Rostovskoy oblasti (TsDNIRO) [Documentation Centre of Modern History of Rostov Region], F. 4, Op. 1, D. 73.711.

20. Protokoly zasedaniya plenumov Donkoma RKP(b) ot 15 aprelya, 20 maya, 5 iyunya, 8, 3 iyulya № 13, 1 [Minutes of the Meeting of the Russian Communist Party (Bolsheviks) Don Committee Plenums of April 15, May 20, June 5, July 8, 3 no. 13, 1]. Tsentr dokumentatsii noveyshey istorii Rostovskoy oblasti (TSDNIRO) [Documentation Centre of Modern History of Rostov Region], F. 4, Op. 1, D. 74. 471.

21. Raznaya sekretnaya perepiska, tsirkulyary, TsK RKP(b) i TsKK [Different Secret Correspondence, Circulars, the Central Committee of the Russian Communist Party (Bolsheviks) and the Central Control Commission]. Tsentr dokumentatsii noveyshey istorii Krasnodarskogo kraya (CDNI KK) [Documentation Centre of Modern History of Krasnodar Krai], F. 13, Op. 1, D. 24. 1451.

22. Savelyev V.A. Khozyaystvennye predstavleniya krestyanstva i kazachestva v usloviyakh novoy ekonomicheskoy politiki: osobennosti transformatsii (na materialakh Dona i Kubani)
[Economic Views of the Peasantry and the Cossacks in the Context of the New Economic Policy: Transformation Features (Based on the Materials from the Don and Kuban)]. Armavir, Armavirskaya gosudarstvennaya pedagogicheskaya akademiya, 2012.159 p.

23. Skorik A.P., Fedina I.M. Kubanskiy khutor: fazy i povsednevnost topokhronnoy evolyutsii (konets $X V I I I$ - pervaya tret $X X v v$.) [Kuban Khutor: Phases and Everydayness of the Topochronic Evolution (Late $18^{\text {th }}-$ First Third of the $20^{\text {th }} \mathrm{c}$.)]. Novocherkassk, Lik Publ., 2016. 420 p.

24. Stenogramma 1-go Oblastnogo syezda Soveta rabochikh, krestyanskikh i kazachyikh deputatov [Shorthand Transcript of the $1^{\text {st }}$ Regional Congress of the Council of Workers', Peasants' and Cossacks' Deputies]. Gosudarstvennyy arkhiv Krasnodarskogo kraya [State Archive of Krasnodar Krai], F. P 102, Op. 1, D. 152. 2551.

25. Stenogramma 1-oy Kubanskoy okruzhnoy konferentsii RKP (b) [Shorthand Transcript of the $1{ }^{\text {st }}$ Kuban District Conference of the Russian Communist Party (Bolsheviks)]. Tsentr dokumentatsii noveyshey istorii Krasnodarskogo kraya (CDNI KK) [Documentation Centre of Modern History of Krasnodar Krai], F. 8, Op. 1, D. 12. 1101.

26. Stenograficheskiy otchet VI oblastnogo syezda Sovetov Donskoy oblasti. Rech Mikoyana [Shorthand Report of the $6^{\text {th }}$ Regional Congress of the Soviets of the Don Region. Mikoyan's Speech]. Tsentr dokumentatsii noveyshey istorii Rostovskoy oblasti (TsDNIRO) [Documentation Centre of Modern History of Rostov Region], F. 4, Op. 1, D. 23. 5461.

27. Tikidzhyan R.G. Politika sovetskogo gosudarstva «Litsom k derevne» i problemy vzaimootnosheniy kazachestva, krestyanskogo i inogorodnego naseleniya Dona v 1920-e gody ["Facing the Countryside" Soviet State Policy and the Problems of Relations Between the Cossacks, the Peasants and Non-Resident Population of the Don in the 1920s]. Izvestiya vysshikh uchebnykh zavedeniy. SeveroKavkazskiy region. Obshchestvennye nauki [University News. North-Caucasian Region. Social Sciences Series], Rostov-on-Don, 2011, no 3 (163), pp. 46-50.

28. Fedina I.M. Regulirovanie zemelnykh otnosheniy na Kubani v 1920-e gody [Regulation of Land Relations in the Kuban Region in the 1920s]. Istoricheskaya i sotsialno-obrazovatelnaya mysl [Historical and Social-Educational Idea], 2016, vol. 8, no. 2-1, pp. 39-45.

29. Tsirkulyary oblastnogo otdela upravleniya o borbe s belo-zelenymi, chistke militsii, vypolnenii prodrazverstki i perepiska s Kubano Chernomorskim oblastnym upravleniem militsii i otdelskim otdelom upravleniya po etim voprosam [Circulars of the Regional Division of the Office for Suppressing the White and Green, Purging the Police, Implementing the Surplus 
Appropriation System and Correspondence with Kuban and Black Sea Regional Administration of the Police and the Divisional Department of Managing These
Issues]. Gosudarstvennyy arkhiv Krasnodarskogo kraya [State Archive of Krasnodar Krai], F. P 102, Op. 1, D. 9.401 .

\section{Information about the Author}

Yuri A. Yakhutl, Candidate of Sciences (History), Associate Professor, Department of Russian History, Kuban State University, Stavropolskaya Street, 149, 350040 Krasnodar, Russian Federation, a075ca@yandex.ru, https://orcid.org/0000-0002-6750-4110

\section{Информация об авторе}

Юрий Асланбиевич Яхутль, кандидат исторических наук, доцент кафедры истории России, Кубанский государственный университет, ул. Ставропольская, 149, 350040 г. Краснодар, Российская Федерация, a075ca@yandex.ru, https://orcid.org/0000-0002-6750-4110 